\title{
A Multilevel Research on the Factors Influencing Employee Loyalty Under the New Employer Economics
}

\author{
Xin Zhong ${ }^{1}$, You Xin Zhang ${ }^{1}$, Sheng $\mathrm{Li}^{2} \&$ Yue Liu ${ }^{1}$ \\ ${ }^{1}$ School of Business Administration, Southwestern University of Finance and Economics, Chengdu, China \\ 2 Center for Health Policy \& Drug Affairs Operation Management, Chengdu University of Traditional Chinese \\ Medicine \\ Correspondence: Xin Zhong, School of Business Administration, Southwestern University of Finance and \\ Economics, Chengdu, China.
}

The study is supported by Southwestern University of Finance and Economics for young teachers (JBK2001027) and for Education and Teaching reform of Central University.

\author{
Received: April 28, 2020 \\ Accepted: May 27, 2020 \\ Online Published: June 15, 2020 \\ doi:10.5430/bmr.v9n2p1 \\ URL: https://doi.org/10.5430/bmr.v9n2p1
}

\begin{abstract}
Existing research shows that scholars try to achieve the goal of employee loyalty through human resource management practices at the organization level. However, the new employer economics proposes a tendency from "employer-centered" to "employee-centered". Through a multi-level research method, this paper used 40 teams and found that employer brands had a significantly positive effect on employee loyalty. Basic psychological needs played a mediating role between employer brand and employee loyalty, but the team identification didn't mediate the relationship between employer brand and employee loyalty. At last, the moderating role of servant leadership between employer brand and employee loyalty was not proved.
\end{abstract}

Keywords: new employer economics, employee loyalty, employer brand

\section{Introduction}

Employee loyalty has always been a hot topic of discussion and research in the field of human resource management, which refers that employers endeavor to keep employees for achieving business goals. In fact, employees are the subjects who actually make the decision to leave or stay (Frank, Finnegan, \& Taylor, 2004). Employees make the efforts depending on the employer striving for their retention and matching with their own basic psychological needs. Under the new employer economics, we must switch from "employer-centered" to "employee-centered". Employee loyalty reflects a long-term commitment of employees to the business. Therefore, we need follow the definition of employee loyalty to study the influencing factors, and accurately speaking, starting with the basic psychological needs of employees.

From the perspective of marketing, employees are regarded as the internal customers of the organization. Employer brand is regarded as internal marketing of employer to employees, and the goal of internal marketing is employee loyalty. However, comparing this process from external marketing to internal marketing, we find that the way the company making efforts for employees and customers is different, but the ultimate goal is to achieve a deal. As a result, the success of a company is linked to continuous maintain such trading relationships with employees and customers. This paper regards the continuous transaction relationship between the company and the employee as employee loyalty, and the continuous transaction relationship with customer is considered as repeated purchase behavior. In the study of customer repeat purchase behavior, customer satisfaction is generally used as a cause variable. Satisfaction is a state of mind which means the basic psychological needs are satisfied. Therefore, the possible influencing mechanism of team employer brand on employee loyalty is due to the satisfaction of employees' basic psychological needs. Furthermore, the influencing mechanism might also reflect in the sense of team identification which can stimulate the active behavior of employees. The employee loyalty is the concrete manifestation of identification with the team.

Greenleaf (1970) pointed out that servant leadership always put employee's benefit at the first place, trying to make employees "healthy, smarter, freedom, independent", and the main motivation was to service rather than supervise. 
Farling, Stone and Winston (1999) argued that servant leadership included two components: behavior (vision, service) and relationship (impact, credibility, trust). Servant leadership was significantly positively related to employee organizational trust and supervisor trust (Joseph \& Winston, 2005), employee's perception of fairness, job satisfaction, and emotional belonging (Reinke, 2004). Servant leaders is an effective leadership behavior and has surpassed other leaders in predicting employee attitudes and behaviors. The moderating effect of servant leadership has been demonstrated by some studies (Bauer, Perrot, Liden, \& Erdogan, 2019; Wu, Qiu, Dooley, \& Ma, 2019).

Our study makes several contributions to the existing literature of employee loyalty. First, the article integrates a multi-level perspective to explore the mechanism between employer brand and employee loyalty. On the one hand, route 1 uses the model of "stimulus-perception-behavior" in dynamic psychology to test the important role of basic needs of employees. On the other hand, route 2 studies how team employer brand through team identification affects employee loyalty (behavior). Second, there is a current lack of researches about the contextual factors, which may affect the relationship between employer brand and team identification at the team level and between employer brand and employee psychological need at the individual level, and our study just fills this gap. The theoretical model is shown in Figure 1.

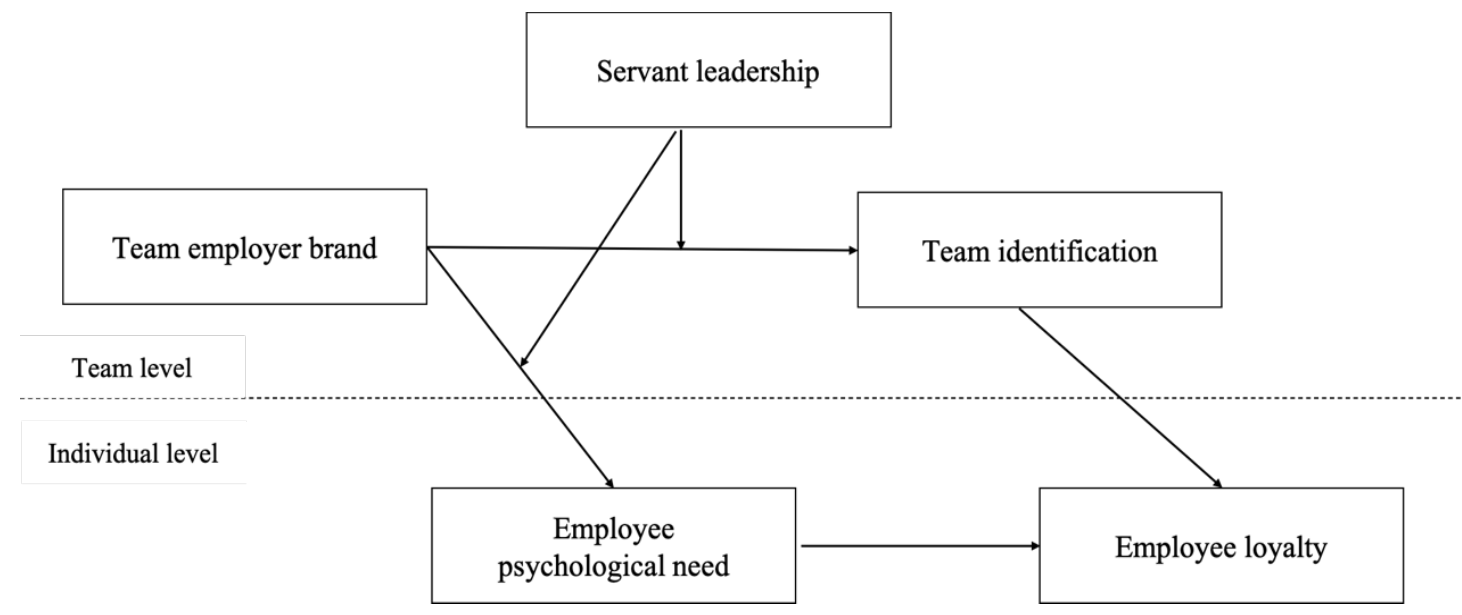

Figure 1. Theoretical Model

\section{Literature Review}

\subsection{Team Employer Brand Affect Employee Loyalty}

Existing research shows that team employer brand reflects employee sense of their employment experience (Barow \& Mosely, 2005). Employee loyalty is influenced by team's employment brand, and a good team employer brand has a positive effect on employee loyalty (Priyadarshi, 2011) and brand affect (Tayyaba et al., 2018). Prior study used questionnaires to examine the loyalty of the employee and their employer brand. Using empirical analysis, the results showed that employee loyalty was significantly related to employer brand. The better the employer's brand building, the higher the employee loyalty. Therefore, this paper proposes the hypothesis that:

\section{H1: The team employer brand has a positive impact on employee loyalty.}

\subsection{The Mediating Role of Employees' Basic Psychological Needs and Team Identification}

At the individual level, self-determination theory illustrates how the environment affects individual behavior, and its link to positive psychology and active organizational behavior (Deci \& Ryan, 1985). According to self-determination theory, the environment has an important influence on individual's basic psychological need satisfaction (Deci, 2000). For employees, the largest environment is the organization. Employer branding is the corporate image established through the workplace, which makes the company different from other companies and become the optimal working environment (Ewing et al., 2002; Berthon, Ewing, \& Hah, 2005). If an organization is perceived by individuals and have a sense of integration, the organization must be understood and recognized by individuals at first. The foundation of employer branding is the perception of employees in the organization, namely, employment experience. This employment experience directly affects the satisfaction of employees' basic psychological needs (Dave, 2001). 
If the basic psychological needs are satisfied, it can promote individual's positive behavior and attitude. Past studies have shown that satisfaction of basic psychological needs was positively correlated with better work performance (Greguras \& Diefendorff, 2009), more engaged work attitude (Deci et al., 2001) and better psychological state (Gagné \& Deci, 2005).

From the perspective of cognition, organizational identification is defined as the cognitive process in which individuals produce a sense of oneness or belongingness with an organization, which enables individuals and organizations to reach agreement on values (Ashforth \& Mael, 1989). De Cremer (2005) first put forward the concept of team identification, believing that team identification is that many individuals replace their own ideal with the same goal, and then identify with each other and the common goal of the team. One of the main objectives of employer brand is to encourage existing employees to identify with the organization (Edwards, 2005; Martin, 2008). In addition, organizational identification can motivate and help guide employees' behaviors by endowing them value (Ashforth \& Mael, 1996). Moreover, the levels of identification and loyalty of employees to the organization are positively correlate with the performance at work (Mael \& Ashforth, 1992), which stimulates organizations to build their own employer brand for getting a higher degree of identity from potential or existing employees. In fact, compared with organizations, employees are more likely to identify with the work teams they work with on daily life, which makes the team identity show more significant predictive power to employees' behaviors at workplace. Therefore, team identification has a far greater impact on employees' behaviors than organization identification (Riketta \& van Dick, 2005). Therefore, we predict that:

\section{H2: The team employer brand has a positive impact on team identification.}

H3: The team employer brand has a positive impact on individual employees' basic psychological needs.

H4: Team identification mediates the relationship between team employer brand and employee loyalty.

H5: Individual employees' basic psychological needs mediates the relationship between team employer brand and employee loyalty.

2.3 The Moderated Mediation Effect of Servant Leadership on Employer Brand, Team Identification, Basic Psychological Needs and Employee Loyalty

Hewitt argued that employer brand, as an image of employers, was reflected in the value, policy and behavior system related to motivating and retaining existing employees and attracting potential employees. And others believed that employer brand was the brand commitment provided by enterprises to employees. In work, employees are often in contact with supervisors and leaders, so the behaviors of leaders affect employees' perception of employer brand to some extent.

At the team level, the "people-oriented leadership behavior" embodied by servant leadership can create a good team atmosphere at the group level (van Dierendonck, 2011), so as to improve team's efficiency and performance, and make the whole organization form a culture of servant leadership. Chinese researchers found that servant leaders would influence the performance of employees at the individual level through service-oriented behaviors at the team level. Moreover, servant leadership at the team level will not only affect employees' short-term work performance, but also affect their long-term work performance through short-term performance.

Thus, from the perspective of social identity theory, a good employer brand can stimulate team identification, and promote the satisfaction of employees' basic psychological needs from the perspective of self-determination theory. Employer brand is the brand commitment of enterprises and employees, and servant leadership has a moderating effect on employer brand, employees and their teams. Therefore, the hypothesis is made.

H6: Servant leadership moderates the indirect relationship between team employer brand and employee loyalty via team identification.

H7: Servant leadership moderates the indirect relationship between team employer brand and employee loyalty via basic need satisfaction.

\section{Research Methodology}

\subsection{Data Collection and Sample}

This paper distributed questionnaires to employees and their supervisors from Sichuan, Yunnan and Chongqing in mainland China to obtain first-hand data through large sample. A total of 40 teams of data, 160 self-test data of employees and 40 pieces of data filled in by supervisors were distributed and collected, all of which were examined as valid questionnaires. 


\subsection{Instruments/Questionnaire}

\subsubsection{Employer Brand}

Employer brand was measured by 25 items developed by (Berthon, Ewing, \& Hah, 2005). A sample item is: "Working in an exciting environment". Scores were averaged, and higher scores indicated higher levels of employer attractiveness.

\subsubsection{Team Identification}

Team identification was measured by 2 items developed by (Baron \& Kenny, 1986). A sample item is: "To what extent does the group member identify with the team?". Scores were averaged, and higher scores indicated higher levels of team identification.

\subsubsection{Basic Psychological Need Satisfaction}

Nine items from Deci (2000) was used to assess need satisfaction. An example of items is: "I feel a lot of closeness and intimacy". Scores were averaged, and higher scores indicated higher levels of need satisfaction.

\subsubsection{Servant Leadership}

We used a fifteen-item scale to measure servant leadership (Barbuto \& Wheeler, 2006). A sample items is: "This person puts my best interests ahead of his/her own"'. Scores were averaged, and higher scores indicated higher levels of servant leadership.

\subsubsection{Employee Loyalty}

We used a seven-item scale to measure employee loyalty (Yao, Huang, \& Fan, 2008). It includes attitude and behavior loyalty. Sample items are: "Working in this enterprise is my best choice" and "I wouldn't leave the company without major reasons". Scores were averaged, and higher scores indicated higher levels of employee loyalty.

\section{Results and Findings}

In this paper, multilevel research method is adopted to pair team data with employee data to find out the influencing factors of employee loyalty at the individual level and team level. In addition, SPSS 22 and STATA 14.0 were used for data analysis.

Table 1. Results of Stata analysis

\begin{tabular}{|c|c|c|c|c|c|c|c|}
\hline & \multicolumn{2}{|c|}{ Team identification } & \multirow{2}{*}{$\begin{array}{l}\begin{array}{l}\text { Employee } \\
\text { need }\end{array} \\
\text { coefficient } \\
\text { (SE) }\end{array}$} & \multirow{2}{*}{$\begin{array}{l}\text { psychological } \\
\text { coefficient } \\
\text { (SE) }\end{array}$} & \multicolumn{3}{|c|}{ Employee loyalty } \\
\hline & $\begin{array}{l}\text { coefficient } \\
\text { (SE) }\end{array}$ & $\begin{array}{l}\text { coefficient } \\
\text { (SE) }\end{array}$ & & & $\begin{array}{l}\text { coefficient } \\
\text { (SE) }\end{array}$ & $\begin{array}{l}\text { coefficient } \\
\text { (SE) }\end{array}$ & $\begin{array}{l}\text { coefficient } \\
\text { (SE) }\end{array}$ \\
\hline intercept & $\begin{array}{l}0.58^{* *} \\
(0.17)\end{array}$ & $\begin{array}{l}-0.24 \\
(0.47)\end{array}$ & $1.12^{* *}(0.34)$ & $\begin{array}{l}3.32^{* *} \\
(0.84)\end{array}$ & $\begin{array}{l}1.23^{* *} \\
(0.48)\end{array}$ & $1.22^{*}(0.49)$ & $\begin{array}{l}0.95^{*} \\
(0.45)\end{array}$ \\
\hline Team employer brand & $\begin{array}{l}0.83^{* *} \\
(0.04)\end{array}$ & $\begin{array}{l}0.77^{* *} \\
(0.17)\end{array}$ & $0.68^{* *}(0.09)$ & $\begin{array}{l}-0.49 \\
(0.30)\end{array}$ & $\begin{array}{l}0.47^{* *} \\
(0.12)\end{array}$ & $0.45^{*}(0.22)$ & $\begin{array}{l}0.29^{*} \\
(0.12)\end{array}$ \\
\hline Servant leadership & & $\begin{array}{l}0.55^{* *} \\
(0.18)\end{array}$ & & $\begin{array}{l}-0.23 \\
(0.32)\end{array}$ & & & \\
\hline $\begin{array}{l}\text { Team employer brand } \mathrm{X} \\
\text { Servant leadership }\end{array}$ & & $\begin{array}{l}-0.07^{+} \\
(0.04)\end{array}$ & & $\begin{array}{l}0.21^{* *} \\
(0.07)\end{array}$ & & & \\
\hline Team identification & & & & & & $0.03(0.22)$ & \\
\hline $\begin{array}{l}\text { Employee basic need } \\
\text { satisfaction }\end{array}$ & & & & & & & $\begin{array}{l}0.26^{* *} \\
(0.05)\end{array}$ \\
\hline
\end{tabular}

Notes. leader sample $=40 ;$ employee sample $=160 ;+\mathrm{p}<.10 ; * \mathrm{p}<.05 ; * * \mathrm{p}<.01$.

First, the hypothesis that team employer brand is significant positively correlated with employee loyalty is tested (coefficient $=0.47$, standard error $=0.12, \mathrm{p}<.01$ ). Second, team employer brand is significant positively related with team identification (coefficient $=0.83$, standard error $=0.04, p<.01$ ). Third, the hypothesis that employer brand 
perception is significant positively correlated with the basic psychological needs of employees is valid (coefficient $=0.68$, standard error $=0.09, \mathrm{p}<.01$ ). Forth, the hypothesis that the basic psychological needs of employees play a mediating role between team employer brand and the loyalty of employees is demonstrated $(95 \%$ confidence interval $=$ $[0.10,0.26]$, excluding " 0 "). therefore, the routine 1 was totally supported, then we tested the routine 2 . The hypothesis 4 suggests that team identification mediates the relationship between team employer brand and employee loyalty was not supported because of confidence interval $=[-0.34,0.39]$, including " 0 ").

In addition, servant leadership doesn't play roles in the relationship between employer brand and employee loyalty via basic psychological needs and team identification. Specifically, when the servant leadership is high, the indirect influence of employer brand perception on employee loyalty through team identity will be strengthened $(95 \%$ confidence interval $=[-0.23,0.26]$, including " 0 "). The indirect influence of employer brand perception on employee loyalty will be strengthened through the basic psychological needs of employees $(95 \%$ confidence interval $=[-0.06$, $0.14]$, including " 0 "). Hence, neither hypothesis about the moderating role of servant leadership is proved.

\section{Conclusion and Discussion}

Based on self-determination theory and social identity theory, this paper explored the antecedent of employee loyalty. It showed that in the era of borderless career, employer brand was an important factor to increase employee loyalty. In addition, we tested the internal mechanism between employer brand and employee loyalty, revealing the conditioning effect of servant leadership. These conclusions enrich the research content of employer brand and employee loyalty in the following ways.

\subsection{Employer Brand Is an Important Antecedent Variable of Employee Loyalty}

Employer brand significantly affects employee loyalty intention and behavior, which is consistent with the past research (Backhaus \& Tikoo, 2004). This shows that team employer brand is a unique employment experience of employees and a commitment to convey employment value (Dave, 2001), a good match between the satisfaction of employees' basic psychological needs and employment experience and employment value is conducive to promoting employee loyalty. Moreover, in terms of employee loyalty, the basic psychological needs theory holds that people are born with three psychological needs: competence, autonomy and relatedness. All individuals will strive to make their needs satisfied, and tend to stay in the environment that satisfies these basic psychological needs (Deci, 2000). Therefore, good employer brand building creates an environment that meets the basic psychological needs of employees. In such a working environment, employees will develop from compulsory value identity to endogenous value identity.

\subsection{Team Employer Brand is an Important Antecedent Variable of Basic Psychological Needs and Team Identification}

The empirical results of this research show that employer brand has a significant positive impact on the basic psychological needs of employees. It means that, in an organization, employees tend to stay for a long time when their basic psychological needs are satisfied. And this result tests the "stimulus - perception - behavior" theory. The stimulus is an external influence that triggers the recipient's response. Therefore, employer brand, as the perceived employment experience of employees, is a kind of stimulation signal for employees, and it affects the basic psychological needs of employees. In an enterprise, there are implicit agreements between employees and organizations, so employees expect organizations to create various conditions to meet their basic psychological needs. In turn, employees will be loyal to their organization, reduce the tendency to leave, and maintain and defend the implicit and interactive nature of the employer brand of the organization (Kotter, 1973). Therefore, in management practice, to create unique employment experience for employees is helpful to meet the multi-level and multi-type psychological needs of employees, so that enterprises can retain existing employees and create unique competitive advantages.

Employer brand can influence the team identification at the team level, and a good employer brand can improve the team identification of the whole company. Edwards (2005) proposed that one of the main goals of promoting employer brand was to encourage existing employees to identify with the organization. And organization identification can motivate and guide employees' behaviors by giving employees value (Ashforth \& Mael, 1996). In addition, the levels of identity and loyalty of employees to the organization are positively correlated with their active performance in work (Mael \& Ashforth, 1992). Therefore, in order to ensure the enthusiasm, enterprises need to pay attention to the construction of employer brand.

\subsection{The Moderating Role of Servant Leadership}

Existing studies show that external environmental factors such as "servant leadership" can be regarded as a moderator variable, then influence the outcome variable through mediator variable. According to cognitive evaluation theory, individual behavior is influenced by external factors, and leadership style is an important external situation faced by 
employees. Moreover, the empirical results show that servant leadership fails to improve the satisfaction of employees' basic psychological needs, nor can it further improve the probability of employee loyalty. However, for the organization, it will improve its efficiency in completing tasks and allocating resources. The supportive emotions and behavioral characteristics of leaders have a positive impact on the morale of subordinates and form their potential positive behaviors (Dasborough \& Ashkanasy, 2002). Most of the researches on the single behavior of "servant leadership" point out that servant leadership has positive effects on work attitude, positive behavior, mental health. At the same time, good employer brand can stimulate team identification from the perspective of organization identification theory. Moreover, excellent employer brand can promote the satisfaction of employees' basic psychological needs, and then affect employees' loyalty from the perspective of self-determination theory. All suggest that servant leadership has a moderating effect on employees and their teams and employer brand, but the data does not support the hypothesis. Therefore, it can be concluded that the disloyalty of employees may also occur under the behavior of servant leadership, which is just like the Chinese saying, "going too far is as bad as not going far enough". That is to say, good environment, easy interpersonal relationship, effective identification and psychological needs satisfaction cannot bring employees' "real and true" loyalty under certain circumstances.

\section{Limitations and Suggestions for Future Research}

Despite these contributions, our study has several limitations that point to avenues for future research. One limitation is that the self-reported data, which is likely to yield common-method variance (Podsakoff et al., 2012). To control for confounding factors, we recommend future research to employ experimental designs or use multi-source data from a broader source, such as the employees' loyalty from their partners. Another limitation is that the moderated effect of servant leadership hasn't been tested. We encourage future research to examine other possible contextual role, such as ethical leadership, which could stimulate employee loyalty directly (Tseng \& Wu, 2017).

\section{References}

Ashforth, B. E., \& Mael, F. A. (1989). Social identity theory and the organization. The Academy of Management Review, 14(1), 20-39. https://doi.org/10.5465/AMR.1989.4278999

Ashforth, B. E., \& Mael, F. A. (1996). Organizational identity and strategy as a context for the individual. Advances in Strategic Management, 13, 19-64.

Backhaus, K., \& Tikoo, S. (2004). Conceptualizing and researching employer branding. The Career Development International, 9(5), 501-517. https://doi.org/10.1108/13620430410550754

Barbuto, Jr J. E., \& Wheeler, D. W. (2006). Scale Development and Construct Clarification of Servant Leadership. Group \& Organization Management, 31(3), 300-326. https://doi.org/10.1177/1059601106287091

Baron, R. M., \& Kenny, D. A. (1986). The moderator-mediator variable distinction in social psychological research: Conceptual, strategic, and statistical considerations. Journal of Personality and Social Psychology, 51(6), 1173-1182. https://doi.org/10.1037/0022-3514.51.6.1173

Barow, S., \& Mosely, R. (2005). Bringing the Best of Brand Management to People at Work. Sussex: Wiley \& Sons.

Bauer, T. N., Perrot, S., Liden, R. C., \& Erdogan, B. (2019). Understanding the consequences of newcomer proactive behaviors: The moderating contextual role of servant leadership. Journal of Vocational Behavior, 112, 356-368. https://doi:10.1016/j.jvb.2019.05.001

Berthon, P., Ewing, M., \& Hah, L. L. (2005). Captivating company: dimensions of attractiveness in employer branding, Internal Journal of Advertising, 24(2), 151-172. https://doi.org/10.1080/02650487.2005.11072912

Dasborough, M. T., \& Ashkanasy, N. M. (2002). Emotion and attribution of intentionality in leader-member relationships. The Leadership Quarterly, 13(5), 615-634. https://doi:10.1016/s1048-9843(02)00147-9

Dave, L. (2001). Building a Winning Employee Brand. Retrieved from www.erexchange.com

De Cremer, D. (2005). Procedural and distributive justice effects moderated by organizational identification. Journal of Managerial Psychology, 20(1), 4-13. https://doi.org/10.1108/02683940510571603

Deci, E. L., \& Ryan, R. M. (1985). The general causality orientations scale: Self-determination in personality. Journal of Research in Personality, 19(2), 109-134. https://doi.org/10.1016/0092-6566(85)90023-6

Deci, E. L., \& Ryan, R. M. (2000). The "what" and "why" of goal pursuits: Human needs and the self-determination of behavior. Psychological Inquiry, 11(4), 227-268. https://doi.org/10.1207/S15327965PLI1104_01 
Deci, E. L., Ryan, R. M., Gagné, M., Leone, D. R., Usunov, J., \& Kornazheva, B. P. (2001). Need satisfaction, motivation, and well-being in the work organizations of a former Eastern bloc country: A cross-cultural study of self-determination. Personality and Social Psychology Bulletin, 27(8), 930-942. https://doi.org/10.1177/0146167201278002

Edwards, M. R. (2005). Organizational identification: a conceptual and operational review. International Journal of Management Review, 7(4), 207-230. https://doi.org/10.1111/j.1468-2370.2005.00114.x

Ewing, M., Pitt, L., de Bussy, N., Berthon, P. (2002). Employment branding in the knowledge economy, International Journal of Advertising, 21(1), 3-22. https://doi.org/10.1080/02650487.2002.11104914

Farling, M. L., Stone, A. G., \& Winston, B. E. (1996). Servant leadership: Setting the stage for empirical research. Journal of Leadership \& Organizational Studies, 6(1-2), 49-72. http://doi.org/10.1177/107179199900600104

Frank, F. D., Finnegan, R. P., \& Taylor, C. R. (2004). The race for talent: retaining and engaging workers in the 21st century. Human Resource Planning, 27(3), 12-25.

Gagné, L., \& Deci, R. (2005). Self-Determination Theory and Work Motivation. Journal of Organizational Behavior, 26(14), 331-362. https://doi.org/10.1002/job.322

Greenleaf, R. K. (1970). The servant as a leader. Indianapolis, IN: Greenleaf Center. http://doi.org/10.1007/978-3-540-70818-6_6

Greguras, G. J., \& Diefendorff, J. M. (2009). Different Fits Satisfy Different Needs: Linking Person-Environment Fit to Employee Commitment and Performance Using Self-Determination Theory. Journal of Applied Psychology, 94(2), 465-477. https://doi:10.1037/a0014068

Joseph, E. E., \& Winston, B. E. (2005). A correlation of servant leadership, leader trust, and organizational trust. Leadership \& Organization Development Journal, 26(1), 6-22. http://doi.org/10.1108/01437730510575552

Kotter, J. P. (1973). The Psychological Contract: Managing the Joining-up Process. California Management Review, 15(3), 91-99. https://www.jstor.org/stable/41164442

Mael, F., \& Ashforth, B. E. (1992). Alumni and their alma mater: A partial test of the reformulated model of organizational identification. Journal of Organizational Behavior, 13(2), 103-123. https://doi.org/10.1002/job.4030130202

Martin, G. (2008). Employer branding and reputation management: a model and some evidence, in Cooper, C. and Burke, R. (Eds), Peak Performing Organizations (pp. 252-74). Routledge, London.

Podsakoff, P. M., MacKenzie, S. B., \& Podsakoff, N. P. (2012). Sources of method bias in social science research and recommendations on how to control it. Annual Review of Psychology, 63, 539-569. https://doi.org/10.1146/annurev-psych-120710-100452

Priyadarshi, P. (2011). Employer Brand Image as Predictor of Employee Satisfaction, Affective Commitment \& Turnover, Indian Journal of Industrial Relations, 46(3), 510-522. https://www.jstor.org/stable/41149467

Reinke, S. J. (2004). Service before self: Towards a theory of servant-leadership. Global Virtue Ethics Review, 5, 30-57.

Riketta, M., \& Van Dick, R. (2005). Foci of attachment in organizations: A meta-analytic comparison of the strength and correlates of workgroup versus organizational identification and commitment. Journal of Vocational Behavior, 67(3), 490-510. https://doi.org/10.1016/j.jvb.2004.06.001

Tayyaba, M., Shumaila, Q., Qazi, M. A., Hafiz, F. A., Dr Asad, H., \& Amma, G. (2018). The impact of brand loyalty: mediating role of brand affect in Pakistan. Business and Management Research, 7(4), 46-52. https://doi.org/10.5430/bmr.v7n4p46

Tseng, L. M., \& Wu, J. Y. (2017). How can financial organizations improve employee loyalty? The effects of ethical leadership, psychological contract fulfillment and organizational identification. Leadership \& Organization Development Journal, 38(5), 679-698. https://doi.org/10.1108/lodj-07-2015-0142

van Dierendonck, D. (2011). Servant leadership: A review and synthesis. Journal of Management, 37(4), 1228-1261. https://doi.org/10.1177/0149206310380462

Wu, H., Qiu, S., Dooley, L. M., \& Ma, C. (2019). The Relationship between Challenge and Hindrance Stressors and Emotional Exhaustion: The Moderating Role of Perceived Servant Leadership. International Journal of Environmental Research and Public Health, 17(1), 282. https://doi:10.3390/ijerph17010282 
Yao, T., Huang, W. B., Fan, X. C. (2008). Research on employee loyalty in service industry based on organizational commitment mechanism. Management of World, 5, 102-123. 